\title{
Holistic Language Education
}

\author{
Ahmet Egemen Akmençea ${ }^{a}$ Burhan Akpınar ${ }^{b}$, Ezgi Akmençe \\ a Ministry of National Education, Elazig, Turkey \\ b Faculty of Education, Firat University, Elazig, Turkey \\ ${ }^{c}$ School of Foreign languages, Firat University, Elazig, Turkey
}

\begin{abstract}
The purpose of this research is to examine high school students' opinions on Holistic Education and to describe the current situation in education with regard to three dimensions: Teaching Method- Sense Relationship, The Effect of Emotions on learning and Course books in Language Education. Overall purpose of this study is to find a way to improve English Language Learning. Although there are countless researches and studies, Turkish Education System has not found an effective method to teach foreign languages. Therefore, holistic approach may provide a way to enhance this situation. The research was carried out through using a descriptive and scanning model. The universe of the study consists of high school students who study at high schools in Elazığ. 220 high school students from9th, 10th, 11th and 12th grades in Elazığ province participated in the research during 2015-2016 academic year.The scale consists of 3 demographic and 40 likert type questions which are about holistic education. The data was analyzed through using descriptive statistical technique, arithmetic mean, standard deviation, independent groups " $\mathrm{t}$ " test, one way variance analysis (Anova), Mann Whitney $U$ and KWH tests. The results suggest that students are of the opinion that teachers are aware of holistic education and pay attention to the basic principle of this approach. They believed that there is a relationship between emotion and learning. Finally, according to them, course books meet their expectations.
\end{abstract}

\section{ARTICLE HISTORY \\ Received 8 May 2017 \\ Accepted 2 June 2017 \\ KEY WORDS \\ Holistic education; foreign language teaching; emotion} and language; course books

\section{Introduction}

One of the problems Turkish education faces today is about foreign language teaching. This problem causes serious handicaps to adapt to modern world, to reach scientific and technological sources and to have global economy. Therefore, solving this problem is crucial for both improvement of education system and scientific advancement of Turkey.

Foreign language teaching in Turkey dates back to the Ottomans. It started with Arabic and continued by minorities' founding their own schools where they taught European languages. The process reached the peak with westernization efforts of Turkey. Although language teaching in Turkey has a very long history, it still has some drawbacks. Although institutional and personal efforts have been made by spending huge amount of time and financial sources, a desired success has not been obtained (Kuzu, 2013).According to Ministry of Education, this problem stems from the curriculum, however, despite the changes; it is difficult to say that there has been any considerable improvement in learning foreign languages. (Demirpolat, 2015: 7).Surprisingly, students in Turkey have approximately 
700-800 hours English lessons during compulsory education and through university education as well, yet the results of the education are not satisfying at all. There are many reasons for this problem. Among these, lacking motivation and method problems step forward (Arslan and Akbarav, 2010). Therefore, alternative methods need to be provided to tackle with language teaching problems. One of these alternative methods, as suggested by this paper, is holistic approach.

\section{History of Holistic Education}

Holistic education movement drew attention of the World in 1980 in USA. It was a kind of reaction to mechanic- Newtonian education. Madrasahs can be given as examples of Holistic approach in our culture and civilization in an historical process. The Madrasahs which were founded in 1300's both met students secular needs by providing astronomy, physics and mathematics lessons and spiritual needs through learning Qur'an, Islamic law, Islamic mysticism. These educational institutions whose main goals were to meet the students' physically, mentally and spiritually needs were the most successful institutions until they were closed. Holistic view took place in literature as an Holistic approach thanks to the work of John P Miller's The Holistic Curriculum (1988). There is not much reflection of holistic education to Turkish Education System and the Turkish education literature. The most observable reflection of this approach can be seen in the educational reforms of primary schools system in 2004. Curriculum reform in 2004 which was prepared by MEB adopts constructivist and multiple intelligence points of view.

\section{What is Holistic Education?}

Holistic approach in education does not view learners just as mental objects, but aims to improve them mentally, emotionally and physically altogether (Miller, 1992). Thus, they might live in a harmony with society as well as they achieve a higher understanding of other people. Palmer (1998) states that in modern education, mind and heart, reality and emotion, theory and practice, teaching and learning have been seperated from each other.This situation causes a problem in which learners cannot obtain an aim of acquiring and using what they learned or regard English as an ordinary school course. The role of traditional methods in the unsuccessful status of English teaching is undeniable. However, there is always a relationship between culture and language and in culture-related foreign language teaching, the emotional status and the attitude of students toward the course are essential. Therefore Holistic education may serve an alternative solution in learning a foreign language by means of improving students in many aspects. The main purpose of this research is to find out the student's opinions and compare them according to demographic variations. To perceive their opinion better, the questions were divided into three sub-dimensions.

\section{Method}

A descriptive and scanning model was used in the research. 220 high school students from 9th, 10th, 11th and 12th grades in Elazığ province participated in the research during 2015-2016 academic year. 112 of the participants are female and 98 of them male. 53 of the students are 9th grade, 103 of them 10th grade, 45 of them 11th grade and of them are 12th 
grade students. The participation was based on volunteerism. Informed consent was taken from the students. The research data was obtained through Likert type 40 English course related questions scale and five demographic questions. The scale which was prepared AS based on a methodology got its final shape with validity and reliability tests after pilot scheme. After validity and reliability were confirmed, the scale was checked by several English teachers and two members of Firat University Faculty of Education. The scale was applied to the high school students by the researcher himself. The data was analyzed through the use of descriptive statistical technique, arithmetic mean, standard deviation, independent groups " $\mathrm{t}$ " test, one way variance analysis (Anova), Mann Whitney $\mathrm{U}$ and $\mathrm{KWH}$ tests. The findings are given in tables and discussed in relation with the literature.

\section{Findings}

The students' opinions on Teaching Method and Sense Relationship, The Effects of Emotional State on Learning and Course Books in Language Teaching are presented below.

\section{Students' Opinions on Teaching Method and Sense Relationship (TMSR)}

Participant students' opinions on TMSR are shown on Table 1.

Table1 Students' Opinions on Teaching Method and Sense Relationship

\begin{tabular}{lllll}
\hline & Questions & \multicolumn{1}{c}{ SS } & N \\
\hline 1. & Our teacher's teaching method addresses our multi-senses & 3,93 & 1,14 & 220 \\
2. & Our teacher addresses mostly our visual senses (visual teaching) & 3,55 & 1,15 & 220 \\
4. & Our teacher tries to improve us mentally & 3,96 & 1,13 & 220 \\
5. & Our teacher pays attention to our emotions (attitude and behavior) & 3,84 & 1,21 & 220 \\
7. & During lesson, our teacher pays attention to our personal features & 3,20 & 1,39 & 220 \\
8. & Our teacher asks about our opinions while choosing amethod for lessons & 3,70 & 1,26 & 220 \\
9. & Our teacher shares with usthe reasons why he/she choosesa specific method & 3,69 & 1,30 & 220 \\
10. & The methods our teacher uses are suitable for us & 3,78 & 1,24 & 220 \\
12. & Our teacher uses communicative methods & 4,13 & 1,01 & 220 \\
15. & Our teacher help us build our own ideas and opinions & 3,94 & 1,14 & 220 \\
16. & Our teacher listens to our questions carefully and patiently & 4,24 & 1,16 & 220 \\
17. & Our teacher uses more than one method during a lesson & 3,86 & 1,19 & 220 \\
18. & Our teacher tries hard to get us to understand the subject & 4,06 & 1,17 & 220 \\
20. & Our teacher tries hard to make us successful in lessons as well as in real life & 3,63 & 1,39 & 220 \\
27. & The language education I focuses on mental development & 3,09 & 1,26 & 220 \\
& Total (TMSR) & 3,78 & & \\
\hline
\end{tabular}

According to the table 1, the students answered the questions about TMSR sub-dimension as "frequently" $\left(\bar{X}_{\mathrm{TMSR}}=3,78\right)$. This finding can be related to tjat teachers who use multiple teaching methods and having a holistic attitude. It can be expected that these preferences of teachers' will likely improve the academic achievement of students in English teaching.It is because the multi-sensory teaching affects the quality of teaching positively. This finding matches with Bilgin's(2003) study which reports that there is a relationship between 
teaching methods and academic achievement. Hence, the more teaching is organized to address different senses, better results can be taken. Therefore, in order to increase students' attention, in order to make learning more permanent and in order to use the time more efficiently, teachers should address more than one sense. This is very crucial for foreign language instruction. For acquiring a language, hearing itself is not enough. Using colorful visuals and videos, bringing different objects to the classroom environment, and allowing students to touch and observe the objects, make them listen the foreign language spoken by a native speaker. All these ways are much more effective than plain narration.

As parallel to this line of thought, Akpinar (2009), in his multi-sensory foreign language teaching research, states that similar to the natural learning mechanism, multisensory teaching methods which supports the idea of stimulus/transmitting message to the people who have different level of intelligence may contribute to the quality of teaching significantly. He states that advantage of multi-sensory strategies is not only meeting the needs of different learning styles but also learning environments which are organized through this approach may contribute to improve learners' foreing language learning skills . Besides, due to the fact that this multi-channel strategy stimulates every parts of brain it can be said that this approach matches with brain functions.

There is a significant difference among students' opinions based on gender (MWU $=4977,000 ; p=0,033$ ) as seen in table 1 . According to the analysis of these Nonparametric questions, more female students $\left(\mathrm{MR}_{1}=118,70\right)$, are of the opinion that foreign language teachers' should pay more attention to method- sense relation than male students $\left(\mathrm{MR}_{2}=100,29\right)$. This result can be associated with female students' having more emotional attitude toward their teachers.

Moreover, there is a significant difference among students' opinions based on department $(\mathrm{KWH}=20,089 ; \mathrm{p}=0,000)$. At state high schools, students can organize their courses through selective courses. MWU Test which was applied for these Non-parametric items shows that these differences are among 1st and 4thGroup (MWU=570,000; $\mathrm{p}=0.000$ ), and 3rdand 4thGroup ( $M W U=447,500 ; \mathrm{p}=0,0000$ ). Therefore; more number of language department students are successful $(M R 4=64,61)$, compared to science department students $(M R 1=42,51)$ and literature department students (MR3=39,49)are of the opinion that there is a strong relationship between method and sense during foreign language lessons. The possible reason of this result may be because of the fact that the foreign language department students are more accustomed to foreign language teaching and more aware of the importance of multi-sensory methods.

Finally, there is a significant difference among the students' opinions based on their grades $\left(\mathrm{F}_{3-216}=4,417 ; \mathrm{p}=0,005\right)$. Scheffe test which was applied for these parametric questions shows that there is a difference between opinions of 10th - 12th and 10th -12th grade students about holistic approach. More 12th grade students $\left(\bar{X}_{4}=64,47\right)$, are of the opinion that there is a strong relationship between method and sense during foreign language lessons compared to the 11 th grade students $\left(\overline{X_{3}}=53,26\right)$ as well as 10thgrade students $\left(\bar{X}_{2}=56,05\right)$. This might be because 12th grade students compared to the 10th and 11th grades are more mature and have a better relationship with their teachers.

\section{Students'Opinions about the Effects of Emotional State on Learning (EES)}

The participant students' opinions on EES are shown on Table 2.According to table 2, the students answered the questions of EES sub-dimension as "sometimes" ( $\left.\bar{X}_{\mathrm{EES}}=2,73\right)$. This 
finding may be related to the students not regarding emotional, spiritual and physical problems as obstacles for language learning. However, Bloom and many others put forward that there is a strong relationship between learning and emotional state (Sönmez, 2008). Therefore; it can be said that teachers' attendance to the emotional state of students "sometimes" is an essential incompetence. Such opinions of students may be related to their status which might be under an emotional and spiritual pressure during adolescence period and they may not want to show these to other people or they may try to prove themselves to the adults. This finding of the research matches Keleş's study (2006) on brain and learning. According to Keleş, the research on neuroscience can provide significant information about the main factors which affect learning. Main factors affecting learning can be listed as memory, patterning, attention, environment, emotions, motivation, diet, water and sleep. The studies on neuroscience have found out crucial information putting forward the effect of emotion on learning. LeDoux (1998)suggest that in every experience, brain automatically bounds the emotions and thoughts. A person having positive or negative thought in a learning environment may cause different variations and releasing various chemicals. For instance, pleasurable learning environments may cause endorphin to be released in brain. Endorphin, which is a natural drug, causes a person to relax and have a more enjoyable learning experience. (Wortrock, 2002; Özden, 2003; Wolfe, 2004). Learning conditions may cause an anxiety under pressure and it is difficult to say learning will happen out functionally under such circumstances.

Table2 Students' Opinions about Effects of Emotional State

\begin{tabular}{llccc}
\hline & Questions & $\bar{X}$ & SS & N \\
\hline 31. & Emotional problems affect my foreign language learning negatively & 2,82 & 1,48 & 220 \\
32. & Spiritual problems affect my foreign language learning negatively & 2,67 & 1,38 & 220 \\
33. & Physical problems affect my foreign language learning negatively & 2,69 & 1,46 & 220 \\
& Total (EES) & 2,73 & & \\
\hline
\end{tabular}

According to the independent group " $\mathrm{t}$ " test, seen in Table 2, there is no significant difference among students' opinions based on gender $(\mathrm{t} 218=-0,716 ; \mathrm{p}>0,05)$. This result shows that there is no difference between male and female students about emotional state as previously thought and it can be said that they are equally mature.

"Anova" test was applied to find out whether there is a difference among students' opinions on Table 2 based on their department. It has been found out that the students' opinions are not affected by their department. ( $F 3-216=0,182 ; \mathrm{p}>0,05)$.

\section{Students' Opinions about Course Books in Language Teaching (CBLT)}

Participant students' opinions on CBLT are shown on Table 3. 
Table 3 Students' Opinions about Couse Books in Language Teaching

\begin{tabular}{llccc}
\hline & Questions & $\bar{X}$ & SS & N \\
\hline 35. & English course books are suitable for our level & 3,88 & 1,23 & 220 \\
36. I like the physical features of English Couse books (size, paper quality etc.) & 3,43 & 1,40 & 220 \\
37. English Couse books focus on only giving information & 3,40 & 1,28 & 220 \\
Total (CBLT) & 3,57 & & \\
\hline
\end{tabular}

According to table 3, the participant students answered the questions related to course books how "frequently" $\left(\bar{X}_{\mathrm{CBLT}}=3,57\right)$ they meet their needs. This finding can be interpreted as the course books which have been prepared by MEB have reached a satisfying point after being revised each year. One of the main principles of the constructivist approach is that teachers and course books do not give the information directly to the students but they provide suitable environment for them to construct their own opinions.(Driver and Bell, 1986; Widodo, Duit and Müller, 2002; Küçüközer, 2004).

There appears no significant difference among the students' opinions about course books based on gender variation $\left(\mathrm{t}_{218}=1.108 ; \mathrm{p}>0,05\right)$. Both male and female participant students have mostly positive thoughts on course books."Anova" test was applied to find out whether there is a difference among the students' opinions based on their department and it has been found that their opinions are not affected by their department. $\left(\mathrm{F}_{3-216}=0,444 ; \mathrm{p}>0,05\right)$. It can be said that with visually attractive pages, listening and speaking activities in every unit, English course books meet the requirements.

Finally, "Anova" test was applied $\left(\mathrm{F}_{3-216}=1,209 ; \mathrm{p}>0,05\right)$ to find out whether there is a difference among the students' opinions based on their grades. The results indicate that there is not a significant difference. In other words, the participant students have similar opinions about course books.

\section{Conclusion}

The main purpose of this research was to explore the students' opinions about holistic education. Data was collected through a scale of holistic education. It was seen that teachers' paying attention to the relationship between teaching methods with sensory organs is suitable for the nature of constructivist approach and is parallel with contemporary education and training approaches by putting forward multiple messages into education. The main issue here is that choosing appropriate methods for students of multiple senses is not enough to achieve a holistic approach. For Holistic education, the curriculum should be designed according to the holistic approach and the teachers should be willing to adopt it. Holdstock (1987) states that our source of knowledge is made up of pieces and it is impossible to understand the whole without understanding all these small pieces. The finding of the study suggests that female students have more positive attitudes towards holistic education than male students. Besides, the higher grade the students are, the better perception they have.

According to Ron Miller (1997), holistic education is a multi-dimensional concept which covers social, cultural and democratic education. Miller regards holistic education as a democratic education related to social responsibilities and personal freedom. Miller thinks that children should be given freedom of choosing, freedom of following their interests, freedom of criticism. 
It has been found out that high school students regard emotional, spiritual and physical problems "sometimes" as obstacles for language learning. However, in the literature it is argued that emotional features can be very effective on language learning. The main reason of this result may be that the studentsare not aware of the effect of emotion on language learning, not having an idea about the literature and not knowing anything about holistic approach and mental and emotional relationship.

In constructivist education approach, course books are regarded as not primary but secondary source of information whereas they are still important source of reference for students (Demiralp,2007). The participant students are of the opinion that foreign language course books "frequently" meet their needs during the learning process. On the other hand; the students answered "sometimes" opinion to the question of "English course books focus on only giving information". This shows that course books do not include information about students' emotional state and do not adopt the holistic approach. Hence, MEB needs to design suitable foreign language course books for the English High School Curriculum which will support holistic development of students.

According to Orion (2007), holistic based education curriculum should have some features such as:

- It should be useful and related to daily life.

- $\quad$ Learning should be organized from concrete to abstract.

- $\quad$ Learning should be organized based on various learning styles.

- $\quad$ Environment should be integrated to learning activities.

- Learning should focus on both mental and emotional aspects of students

In brief, the finding of this study matches the previous studies related holistic approach and holistic education. There is no doubt that holistic education will be a useful alternative for language teaching methods. Students should not be considered as completion of a mechanical system. According to Ron Miller (2005), modernist World view makes people short of values and a kind of robot which runs after endless wish and desires. They have emotional and spiritual features. Especially adolescence is a very critical period in one's life. Therefore. more attention should be given through this period than any other period in ones' life.

Not: Bu yazı, Ahmet Egemen Akmençe’nin yüksek lisans tezinden üretilmiştir.

\section{References}

Akpınar, B. \& Aydın, K. (2009). Çok Duyulu (Multi-Sensory) Yabancı Dil Öğretimi. TÜBAV Bilim Dergisi, 2(1), 99-106.

Arslan, M. \& Akbarav, A. (2010). Türkiye’de Yabancı Dil Öğretiminde Motivasyon-Yöntem Sorunu ve Çözüm Önerileri. Selçuk Üniversitesi Edebiyat Fakültesi Dergisi, 24, 179-191.

Bilgin, İ. \& Soner, D. (2003). Öğrenme Stilleri ile Öğrenci Başarısı Arasındaki İlişki Üzerine Karşılaştırmalı Bir Araştırma. Educational Sciences: Theory \& Practice, 3(2), 381-400. 
Demiralp, N. (2007). Coğrafya Eğitiminde Materyaller ve 2005 Coğrafya Dersi Öğretim Programı, Kastamonu Eğitim Dergisi, 15(1), 373-384.

Demirpolat, C. B. (2015). Türkiye'nin Yabancı Dil Öğretimiyle İmtihanı Sorunlar ve Çözüm Önerileri, SETA Yayınları, Analiz Sayı 131.

Driver, R., \& Bell, B. (1986). Students' thinking and the learning of science: A constructivist view. School Science Review, 67, 443-456.

Holdstock, L. 1987. Education for a New Nation. Johannesburg, Africa Transpersonal Association.

Keleş, E. \& Çepni, S. (2006). Beyin ve Öğrenme. Türk Fen Eğitimi Dergisi, Yıl 3, Sayı 2, Aralık 2006.

Kuzu, H. (2013). Ortaöğretimde Yabancı Dil (Almanca) Öğretiminin Öğrenci Memnuniyeti Açısından Değerlendirilmesi: Anadolu Lisesi Örneği. Unpublished Master’s Thesis. Selçuk Üniversitesi Sosyal Bilimler Enstitüsü.

Küçüközer, H. (2004). Yapılandırmacı Öğrenme Kuramına Dayalı Olarak Geliştirilen Öğretim Modelinin Lise 1.Sınıf Öğrencilerinin Basit Elektrik Devrelerine İlişkin Kavramsal Anlamalarına Etkisi. Balıkesir Üniversitesi Fen Bilimleri Enstitüsü, Unpublished Doctoral Thesis, Balıkesir.

Miller, John P. (1988). The Holistic Curriculum. Universitry of Toronto Press. First Edition: Canada.

Miller, R. (2005). A Response to the Crisis of Our Time. Paper presented at the Institude for Vakarakkoçlues Education in İstanbul, Turkey in November, 2005.

Miller, R. (1992). Defining a Common Vision: The Holistic Education Movement in the U.S. Holistic Education in Practice, 23(2), 20-21.

Orion, Nir (2007). A holistic approach for science education for all. Eurasia Journal of Mathematics, Science \& Technology Education, 3(2), 111-118

Özden, Y. Özden, (2003). Eğitimde Dönüşüm- Eğitimde Yeni Değerler. Ankara: Pegem A Yayıncılık.

Palmer, P., (1998) The Courage to Teach. Exploring the Inner Lanscape of a Teacher's Life (San Francisco: Jossey-BassInc.)

Sönmez, V. (2008). Program Geliştirmede Öğretmen El Kitabı. Ankara: Öğretmen Yayınları

Widodo, A., Duit, R., \& Müller, C. (2002). Constructivist views of teaching and learning in practice: Teachers' views and classroom behaviour. Annual Meeting of the National Association for Research in Science Teaching, New Orleans.

Wortock, J., M. (2002). Brain Based Learning Principles Applied to the Teaching of Basic Cardiac Codeto Associate Degree Nursing Students Using the Human Patient Simulator, Doctoral Thesis, University of South Florida, Florida, USA. 


\section{ÖZET}

\section{Holistik Dil Eğitimi}

Anahtar kelimeler: Holistik eğitim, bütünsel ingilizce öğretimi, lise ingilizce öğretim programları

Eğitimin nihai amacı, bilişsel ve duyuşsal başta olmak üzere bireyi bütünsel olarak dengeli bir şekilde geliştirerek, topluma ve çevreye uyum sağlayabilen iyi vatandaşlar yetiştirmektir. Küreselleşen günümüz dünyasında, İngilizce, bu amaca hizmet eden önemli bir derstir. İngilizce dersinin temel amacı, gelişen ve değişen dünyaya ayak uydurabilecek, ülke dışında süregelen her türlü gelişmeyi takip edebilecek, kendisini ve ülkesini uluslararası platformlarda iyi bir şekilde ifade edebilecek bireyler yetiştirmektir. Nitekim küreselleşen günümüz dünyasında iyi vatandaş yetiştirme amacında, yabancı dilin önemi gittikçe artmaktadir.

$\mathrm{Bu}$ önemine binaen Türkiye'de, ilkokul 2. sinıftan itibaren İngilizce dersi okutulmaktadır. Her kademedeki İngilizce dersi öğretim programları vasıtasıyla okutulmaktadır. Bu amaçla Türkiye'de Milli Eğitim Bakanlığı (MEB) tarafından birçok eğitim programı hazırlanmıştır. Birçok değişikliğe uğrasa da bu programlar, genel itibarıyla sinıflarda geleneksel metotlarla uygulanmaktadır. Bugün İngilizce dil eğitimi konusunda yaşanan başarısızlıkta, sadece bilişsel gelişme odaklı geleneksel metotların payı büyüktür. Oysaki kültürel bağlamlı yabancı dil eğitiminde öğrencilerin duygu ve tutumları kritik öneme sahiptir. Bu durumda, öğretim sürecinde öğrencilerin bütün boyutlardan geliştirilmesini amaçlayan holistik yaklaşım, sorunun çözümünde alternatif açlımlar sağlayabilir. Holistik İngilizce eğitimi, holistik düşünceden referans almaktadır.

Eğitimde holistik (bütünsel) düşünce, öğrenciyi salt zihin odaklı görmeyip, onu zihinsel, ruhsal, duygusal ve bedensel yönleriyle topyekûn geliştirmeyi hedefler. Böylelikle öğrenci, bir yandan tüm yönleriyle topluma uyumlu sağlıklı bireyler haline gelirken, diğer yandan zihinsel anlamda daha üst düzeyde öğrenebilir. Bu araştırmanın amacı, İngilizce öğretiminde holistik yaklaşıma ilişkin öğrencilerin görüşlerini belirlemek ve bu görüşleri çeşitli değişkenlere göre değerlendirmektir.

Araştırma, betimsel nitelikte ve tarama modelinde yürütülmüştür. Araştırmanın evreni, 2015 - 2016 eğitim öğretim yılında Elazığ il merkezindeki MEB’e bağlı Anadolu liselerinde öğrenim gören 9, 10, 11 ve 12. sınıf öğrencilerini kapsamaktadır. Araştırma örneklemi ise, gönüllülük esasına dayalı olarak ilgili ölçeği doldurmayı kabul eden 220 öğrenciden oluşturulmuştur.

Araştırma verileri, öğrenciler için hazırlanmış olan ölçek, üçü demografik bilgiler ve 40’1 İngilizce dersine ilişkin likert tipi maddeden oluşmaktadır. Metodolojiye uygun olarak hazırlanan ölçeğe, pilot uygulamadan sonra geçerlik ve güvenirlik çalışması yapılarak son şekli verilmiştir. Ölçek, araştırmacı tarafından uygulanmıştır. Verilerin analizinde, betimsel istatistiksel tekniklerden aritmetik ortalama ve standart sapma tekniği ile bağımsız gruplar " $\mathrm{t}$ " testi, tek yönlü varyans analizi (Anova), Mann Whitney U testi ve KWH testi kullanılmıştır. Analiz sonucunda elde edilen bulgular, tablolar eşliğinde yorumlanmıştır. Bulguların yorumlanmasında ilgili araştırmalar ve literatürden de yararlanılmıştır.

Öğrencilere göre, öğretmenler, öğretim sürecinde duyuşsal özellikleri ile öğrenmeöğretme sürecinde öğretimin metotları-duyu ilişkisini ise bazen dikkate aldıkları görüşündedirler. Ayrıca öğrenciler, ilgili ders kitaplarının beklentilerini karşıladığı 
görüşündedirler. Bu bulgular ışığında, yıllar süren uğraşlara rağmen kayda değer bir ilerleme sağlayamamış olan Türkiye'deki İngilizce eğitimi, holistik fikrin ışı̆̆ına, çoklu öğrenme ortamlarının hazırlanması, çok duyuya hitap eden materyallerin hazırlanması ve en önemlisi de öğrenciyi çok boyutlu ele alınmasıyla daha iyi noktalara çekilebilir. Yine tüm seviyeden İngilizce öğretmenlerine seminerler veya hizmet içi eğitimlerin verilmesi, eğitim fakültelerinde ve fen-edebiyat fakültelerindeki öğretim programlarına holistik eğitimin eklenmesi uzun vadede İngilizce eğitiminin kalitesini arttırabilir. 